\title{
MARKETS OF FOOD WITH NUTRITIVE AND HEALTH CLAIM: PRODUCERS' AND RETAILERS' PERSPECTIVES
}

\author{
Zaklina Stojanovic, Jelena Filipovic*, Dragan Stojkovic \\ Faculty of Economics, University of Belgrade, Belgrade, Serbia
}

\begin{abstract}
Although food with nutritive and health claims in the Western Balkan countries hasbeen present in this region for more than a decade, it has remained rather understudied. Therefore, the aim of this study was to determine the importance of products with nutritive and health claims in the Western Balkans, using qualitative research techniques. In the study, the prices and margins of the subject product group, distribution channels, demand perception and incentives as well as barriers for the future development of the functional food market were analyzed. The study included five categories of products with nutritive and health claims, whilethe technique of the in-depth interviews was adopted. The total of 29 producers and 26 retailers form all the six countries of the region participated in the research. Even thoughthe studied categories recorded a sales growth in the previous period, a significant increase is expected in the mediumand long term, along with the growth of the living standard - given that products with nutritive and health claims are more expensive than regular ones. The results imply that it is necessary that the level of education regarding the role of food in health preservation should be raised; and that a change inbad eating habits should be influenced. The development of functional food markets also requires a government support and an appropriate legislation.
\end{abstract}

Key words: functional food, nutritive claim, health claim, the Western Balkans markets

JEL Classification: D12, I15, M38

\section{INTRODUCTION}

Although medicine and life sciences started with nutrition and health studies a long time ago, healthy living had been an increasingly salient part of the food market till the end of the 20th century. In recent decades, both the market and the academic research document have increased the consumer awareness

\footnotetext{
* Correspondence to: J. Filipovc, Faculty of Economics, University of Belgrade; Kamenicka 6, 11000 Belgrade, Serbia; e-mail: jfilipovic@ekof.bg.ac.rs
}

and interest in health matters, namely more specifically in foods with nutritive and health claims - the NHC (Kapsak, Rahavi, Childs \& White, 2011; Hojoon, Kyunga, Tae, Reid \& Macias, 2013). Research in the field of economics, marketing, psychology and social sciences, with its varying perspectives on food with health claims, has become orientedtowards the examination of the consumer points of views since the 1990s.

However, health claim foods are not a well-defined category. In most countries, there is no legislative definition of this group of foods. A literature review 
showed that food labelling is an increasingly important field of research (Caswell \& Johnson, 1991; Caswell \& Padberg, 1992; Caswell \& Mojduszka, 1996; Heasman \& Mellentin, 2001; Patel, 2012). Functional foods are established in the Western Balkan countries (WBC), although the majority of consumers are unfamiliar with the term 'functional foods'. A survey of young adults in Croatia (Markovina, Čačić, Kljusurić \& Kovačić 2011) revealed that only 39.4 per cent were familiar with the term, although when provided with the definition (Diplock, Agget, Ashwell, Bornet, Fern \& Roberfroid, 1999), the three-quarters of them reported that they had bought functional foods. Of those who had purchased functional foods, 26.8, 51.5 and 22.1 per cent had bought them regularly, occasionally or rarely, respectively.

Diplock et al (1999) define functional foods as those that 'affect beneficially one or more target functions of the body, beyond adequate nutritional effects, in a way that is relevant to either an improved state of health and well-being and/or the reduction in therisk of disease'. In a nutshell, it can be stated that food with the NHC might improve one's health and diminish their risk of disease (Christidis, Tsoulfa, Varagunam \& Babatzimopoulou, 2011).

The first hypothesis to have been tested is that the NHC products market is not developed in the WBC. The additional hypothesis is that the importance of this market will significantly increase in the future. In the research process, anin-depth interview technique was used. This is a qualitative technique. The research sample consisted of the leading manufacturers and retailers in the WBC.

In the WBC, little attention was paid to products with an HC analysis, both from the consumer's and the producer's points of view. The analysis of the regulatory framework, medical and technological aspects ispresent at an elementary level. The vast majority of the WBC articles about products with health claims (functional food) are published in medical journals or in agricultural journals by the authors whohave medical affiliation or medical background (Koch \& Pokorn, 1999; Ristevska-Jovanovska, 2000; Šobajić, 2002; Miletić, Šobajić i Đorđević, 2008). There are several theoretical articles emphasizing health benefits being derivedfrom the consumption of functional food or from the analyzing of the legal environment and regulations regarding this food type (Stanković $\mathrm{i}$ Đorđević, 2002; Grujić, 2005; Raspor \& Jevsnik, 2008).

Furthermore, several papers have analyzed a possible contribution of marketing and technology to the offer of food with HC (Rogelj, 2000; Dimitrijević-Branković, Baras i Bojović, 2002; Dimić, Vukša i Dimić, 2002; Ristić, 2003; Ljaljević, Durišić, Mališić i Ivanović, 2006). Ž. Stojanović, R. Dragutinović-Mitrović, and M. ZaoucheLaniau (2013) report the results of a shop check survey of products with health and nutrition claims in six WBC's (Bosnia and Herzegovina, Croatia, FYRoM, Montenegro, the Republic of Serbia and Slovenia). The shop check, covering supermarkets, hypermarkets and health food shops, identified 475 products that fitted with the definition of functional foods advanced by A. T. Diplock et al (1999). The three-quarters of such products were sold in super-/hypermarkets and almost two-thirds were of the WBC origin. In keeping with developed markets (Euromonitor, 2012), the prevalence of such products was the greatest in the dairy sector (e.g. probiotic yoghurts).

\section{METHODOLOGY}

This study adopted the in-depth interview technique, which is one of the qualitative techniques. Qualitative techniques are applied in explorative research, since they are considered to be appropriate for the obtainment of better insights into the topic and for the setting-up of hypotheses in future studies in the subject field.

This technique enables a deeper understanding of the behavior, attitudes, motives, etc. as well as the collection of numerous pieces of information in a relatively short period of time. The in-depth interviews werefacilitated by a trained person and they approximately took one hour to complete. The questionnaire generally included open questions with a combination of the given list of answers in some cases; therefore,adiscussion mightbe extended. Taking into consideration that 
the participants had beenselected according to the previously chosen criteria, the opinions expressed in the in-depth interviews should only be considered as typical ofthat segment of the population. The selection of the categories to be studied was based on the linear and specialized shop check made in each WBC.

The following five categories of the N\&H claim productswere in the focus of the research process:

- Dietetic jam (jam for persons suffering from diabetes);

- Milk enriched with vitamins and minerals;

- Yogurts with probiotics;

- Light margarine;

- Juices and nectars enriched with vitamins and minerals.

The main characteristics of the researched product categories are presented in Table 1.

The aim of the IDI is to gain a qualitative understanding of the market for products with nutrition and health claim in the WBC. These interviews allow a faceto-face discussion and yield valuable information towards the consumption of these products.

The producers and the retailers were chosen by their importance in the market of products with the NHC at the national level. In the majorityof the cases, the respondents were marketing managers for the studied categories. Given the fact that the respondents had beenselected according to the previously established criteria, it can be assessed that their opinions were representative for the particular segment in the market. The majorityof the interviewees operate in the dairy, fruit and oil sectors, and the majority of them work in medium-sized and big companies which are the market leaders in their business fields. The research comprised 29 producers and 26 retailers, coming from all the six WBCs. The interviews were conducted in 2011. The included retailers usually dominantly sell food products and their business is based on classic retailing formats, such as: supermarkets, hypermarkets, superettes and minimarkets.

\section{RESULTS}

The markets of the studied categories in the WBC have significantly evolved in the last three years, especially in Serbia, Macedonia and Bosnia. However, there are differences among the studied categories and the countries. Some growth rates are very high because some of the studied categories have only recently been

Table 1 The main characteristics of the investigated products categories included

\begin{tabular}{|c|c|c|c|}
\hline Category & Products & Claims & $\begin{array}{l}\text { Specificity of } \\
\text { products }\end{array}$ \\
\hline $\begin{array}{l}\text { Jam for } \\
\text { persons } \\
\text { suffering } \\
\text { from } \\
\text { diabetes }\end{array}$ & $\begin{array}{l}\text { Jam } \\
\text { sweetened } \\
\text { with fructose } \\
\text { or with } \\
\text { fructose and } \\
\text { sweeteners. }\end{array}$ & $\begin{array}{l}\text { "suitable } \\
\text { for persons } \\
\text { suffering from } \\
\text { diabetes", } \\
\text { "Diet" 30\% } \\
\text { less calories. }\end{array}$ & $\begin{array}{l}\text { Less calories } \\
(30 \% \text { or } 50 \% \\
\text { less), dietetic }\end{array}$ \\
\hline $\begin{array}{l}\text { Yoghurts } \\
\text { with } \\
\text { probiotics }\end{array}$ & $\begin{array}{l}\text { Yogurts } \\
\text { with specific } \\
\text { "probiotic } \\
\text { ferments". }\end{array}$ & $\begin{array}{l}\text { "favourable } \\
\text { effect on the } \\
\text { digestion; } \\
\text { stimulates } \\
\text { digestion and } \\
\text { metabolism" }\end{array}$ & $\begin{array}{l}\text { Specific } \\
\text { ferments } \\
\text { in addition } \\
\text { to regular } \\
\text { ferments } \\
\text { in yogurts, } \\
\text { functional } \\
\text { claim }\end{array}$ \\
\hline $\begin{array}{l}\text { Milk } \\
\text { enriched } \\
\text { with } \\
\text { vitamins } \\
\text { and } \\
\text { minerals }\end{array}$ & $\begin{array}{l}\text { Milk enriched } \\
\text { with a } \\
\text { complex of } \\
\text { vitamins and } \\
\text { minerals. }\end{array}$ & $\begin{array}{l}\text { Vitamin A,D, } 7 \\
\text { vitamins, Ca+ }\end{array}$ & $\begin{array}{l}\text { Both regular } \\
\text { and low } \\
\text { fat milk, } \\
\text { functional } \\
\text { claim }\end{array}$ \\
\hline $\begin{array}{l}\text { Light } \\
\text { margarine }\end{array}$ & $\begin{array}{l}\text { Margarine } \\
\text { with } \\
\text { significantly } \\
\text { reduced fat } \\
\text { content }\end{array}$ & $\begin{array}{l}\text { "Light" } 25 \% \\
\text { fat content" }\end{array}$ & $\begin{array}{l}\text { Reduced } \\
\text { fat content, } \\
\text { functional } \\
\text { claim }\end{array}$ \\
\hline $\begin{array}{l}\text { Nectars and } \\
\text { fruit juices } \\
\text { enriched } \\
\text { with } \\
\text { vitamins }\end{array}$ & $\begin{array}{l}\text { Nectars and } \\
\text { fruit juices } \\
\text { enriched } \\
\text { with several } \\
\text { vitamins or } \\
\text { contains } \\
\text { specific } \\
\text { nutrient. }\end{array}$ & $\begin{array}{l}\text { Multi-vitamin, } \\
100 \% \text { fruit } \\
\text { juice, added } \\
\text { vitamins, }\end{array}$ & $\begin{array}{l}\text { Dodati } \\
\text { vitamini ili } \\
\text { sastojci; } \\
\text { funkcionalna } \\
\text { izjava }\end{array}$ \\
\hline
\end{tabular}

Source: Authors 
introduced to the market. In general, all of the studied categories have recorded a sales increase in the last three years onthe WBC markets. The more developed markets have lower growth rates since they are more saturated and consumer awareness is higher in these countries. In the less developed WBCs, the growth rates have been higher and will continue higher in the future. More consumers are expected to accept NHC products with the growth of the living standard and the consumer's education.

\section{Price}

The producers charge higher prices for almost all ofthe studied categories (except for light margarine). However, that does not mean that they charge a higher margin for all the products, given the fact that the production process for some products with NHC is more expensive than for the regular products. Consequently, the price of the product is higher. For example, the production of jam for people suffering from diabetes is more expensive than the production of regular jam because fructose is used instead of sugar and the content of fruit is higher. In addition, imported brands from large European producers are present in the WBC markets. The retailers charge the same margins for products either with or without $\mathrm{NHC}$ in all of the investigated categories.

The dairy sector is rather heterogeneous in terms of margins for products with NHC. The producers of yoghurt with probiotics claim they do not charge higher margins; however, most of them state that the price of this yoghurt is higher compared to regular yoghurt. The explanation is that the production of yoghurt enriched with probiotics is more expensive (includes specific ferments). Most producers agree that the price of milk enriched with vitamins and minerals is higher than the price of regular milk. However, half of the interviewed producers claim that they charge the same level of margin as for regular milk. Several producers stated that they charged higher margins for this product, while there was one producer who claimed that he charged lower margin for this type of milk. Therefore, we may come to a conclusion that the margin policy is the least uniform in this studied category. For the most part, the light margarine producers claim that they charge the same margins compared to normal margarines. However, the prices differ from regular margarines. The price of light margarine is usually lower than the price of normal margarine because of the reduced oil content. Regular light margarine has a lower price than normal margarine.

Similarly to the previous findings, most WBC producersofnectars enriched with vitamins and minerals claim that they do not charge higher margins. Yet, some of them stated that they did charge higher margins for these products. However, most of them admit that the price of these juices is higher compared to regular juices. Higher prices could be explained by higher margins and some additional costs of enriching juice with vitamins.

It can be concluded that the prices of the products with claim are higher than the prices of regular products due to the more expensive production process, according to the producers. The only exception is light margarine, which is cheaper than regular one.

\section{Distribution channels}

The distribution channels for the studied categories are relatively similar to the general food distribution channels on theWBC markets. However, there are certain differences across the categories and the countries.

The WBC countries have a different level of the development of the distribution channels. Slovenia has the most developed distribution channels similar to the ones in developed EU countries. Modern retail formats such as hypermarkets and supermarkets are dominant in this market with over $75 \%$ of food retailing. Additionally, the retail chains have more than $80 \%$ of the food retail market. Croatia also hasa more developed food retailing structure than the other WBC countries, with the over-50\%-marketshare of modern retail formats and a more significant share of retail chains. In addition, Serbia and Bosnia also have a significant share of retail chains in food retailing,whereasit is lower in Macedonia and Montenegro. In these countries, the role of small independently-owned stores is more significant. 
However, small stores usually have limited assortments and sell products with the highest turnover. Products with the NHC often do not fulfil this criterion.

Retail chains are the main distribution channel for jam for persons suffering from diabetes. Onaverage, more than $70 \%$ of the sales have been generated through retail chains, especially through supermarkets and hypermarkets. In addition, this product is often offered in the section called the "Healthy Food". In less developed countries, the role of smaller stores is more significant in overall food retailing, althoughthese stores usually do not havedietetic products in their assortments or they have avery limited number of items. In some countries, such as Serbia, there are specialized stores for healthy food that also participate in sales for this category. In addition to this, a certain percentage of sales have been generated through wholesale channels. Distribution through institutional buyers, such as hospitals,stands for a significant channel in Slovenia as well as in some other countries. To add, this product can be bought atpharmacies and drugstores as well.

"It's a trend nowadays for the consumer to be oriented towards supermarkets. This is true for every category of products. In general, analytical data abouta global level show that the highest turnover is made by retail chains. Their advantage is that you can get most of the things you need in one place, in one supermarket. On the other hand, the advantage of other distribution chains, such as specialized shops for dietetic products,lies inthat consumers are in a position to get direct information and explanation about the product they are interested inbuying. But, there is no high turnover here, and another point is that these small shops are unable to be competitive with the prices" (Macedonia, a producer).

Retail chains and especially large stores such as hypermarkets and supermarkets will be dominating the WBC market in this category in the future; these products, however, can be found in smaller shops, especially if they are a part of bigger retail chains.

In line with the previous product category, retail chains are the most important channel for selling yoghurts with probiotics, too. Retail chains generate over $75 \%$ of the sales in this category for the majority of the producers. In addition to this, more than half of the interviewed diary producers only sell through retail chains. Supermarkets and hypermarkets are the leading format in this category as well. However, mini-markets are especially important in less developed WBCs. In Montenegro, for example, 75\% of the sales in this category have been generated through mini-markets. Whatshould be pointed out is that small stores lack a refrigerators space and have a limited assortment of the products thatneed cooling. Producers sell through wholesale especially in less developed WB markets. It is often cheaper to reach small stores through wholesalers. Small stores have limited assortments and often do not haveproducts with NHC. However, due to the producer's marketing efforts, small retailers are sometimes willing to include yoghurt with probiotics in their assortment, especially in urban areas. This product is also beingsold atbakeries. All the respondents claim retail chains will remainthe main distribution channel in the future, followed by an increased share on thehypermarkets' and supermarkets' part.

At least $75 \%$ of the sales of the interviewed producers were generated through retail chains. On average, this percentage is significantly higher. Hypermarkets and supermarkets are dominant in this category. Wholesalers and small stores are important in less developed countries and regions. However, they havelimited assortments of dairy products. They usually purchase regular milk.

\footnotetext{
"In small shops, there are no shelves or such specific products" (Slovenia, a producer).

"Hypermarkets are becoming more and more important for us" (Bosnia and Herzegovina, a producer).
}

Retail chains will increase its importance in this category. Producers expect the hypermarket to be the fastest growing format for this category in the WB markets.

Retail chains dominate in this studied category as well. The interviewed producers generated about $85 \%$ of theirs sales in retail chains. Supermarkets and hypermarkets generate the majority of the sales. However, mini-markets participated with $30 \%$ in retail chain sales. The producers sell about $15 \%$ of 
light margarine through wholesale in Croatia and Serbia. However, this percentage could even be bigger in less developed WBC. Hotels and restaurants are also interesting channels for selling light margarine, especially in countries with the strong tourism industry. In addition to this, margarine requires refrigerators and this selling space is more expensive; therefore, small stores are very selective concerning anassortment thatrequires cooling.

"The most important are retail chains- hypermarkets and supermarkets. Small stores are not insisting on the constant supply of this product. They are interested in products without animal fats during Easter or similar fasting days. In small shops, people only buy the leading brand. But in large stores, they are interested in the price and quality, and are more willing to by our product" (Serbia, a producer).

Retail chains will dominate in the future. However, the expansion of the tourism industry could influence hotels and restaurants to become a significant channel.

Retail chains are the most important distribution channel for this category as well. However, the percentages of the sales generated through retail chains were slightly lower than in the other categories. Wholesalers are more important in this category in comparison with the other studied categories. Consequently, small stores have higher importance, especially in less developed countries and the less developed regions of certain countries. To add to this, the HORECA segment is important for this category. Retail chains still generate at least $50 \%$ of the sales in this category.

"We don't distribute directly, we have distributors who do it for us. Supermarkets and hypermarkets will become more important in the future" (Serbia, a producer).

This category of product is distributed in retail chains and small stores, but we have a significantly better sale in the retail chains" (Macedonia, a producer).

"Supermarkets and hypermarkets are dominant because of the consumer's characteristics" (Serbia, a producer).

The importance of retail chains will increase in the future. However, the HORECA channelshould be taken into consideration as well. Producers will opt for the most efficient distribution.

Retail trends in the WBC markets are positive for $\mathrm{N} \& \mathrm{H}$ claim products. Larger formats will be more important in food retailing inthe future, which will allow retailers to havewider and deeper assortments. In less developed WBCs, supermarkets and hypermarkets will have a much more significant role in the retail market. Therefore, the growth of products with NHC in these countries will be higher due to the changing retailing structure.

\section{Motivations and barriers for the production and sale of products with NHC}

Responding to the consumer demand is the main motive both for the producers and the retailers in the majority of the studied categories, even though their spontaneous answers vary by categories, as it is accounted for in Figure 1. However, consumers are mentioned in several contexts. Theproducers of jam for persons suffering from diabetes, yoghurt with probiotics and light margarines consider answering consumer demand as the main motive for manufacturing products with NHC. Improving the marketing position and a company's image are the following motives. Following the EU trends and generating a profit are the least important motives for producers.

Figure 2 shows us that the regulations and the insufficient knowledge of consumers' needs are perceived as the biggest problems in the development of NHC products. These problems are also highlighted in the producers' spontaneous answers. However, the average grades are not very high (they are up to 3.5). Therefore, these reasons cannot be considered to be serious barriers. The lack of a scientific support in the development of innovation and financial problems are next on the list of barriers. The lack of experts and skills in the field of R\&D is theleast important barrier.

Improving a company's image by selling healthy food and answering the consumer's needs were the most often spontaneously evoked motives by retailers for selling N\&H claim products. 


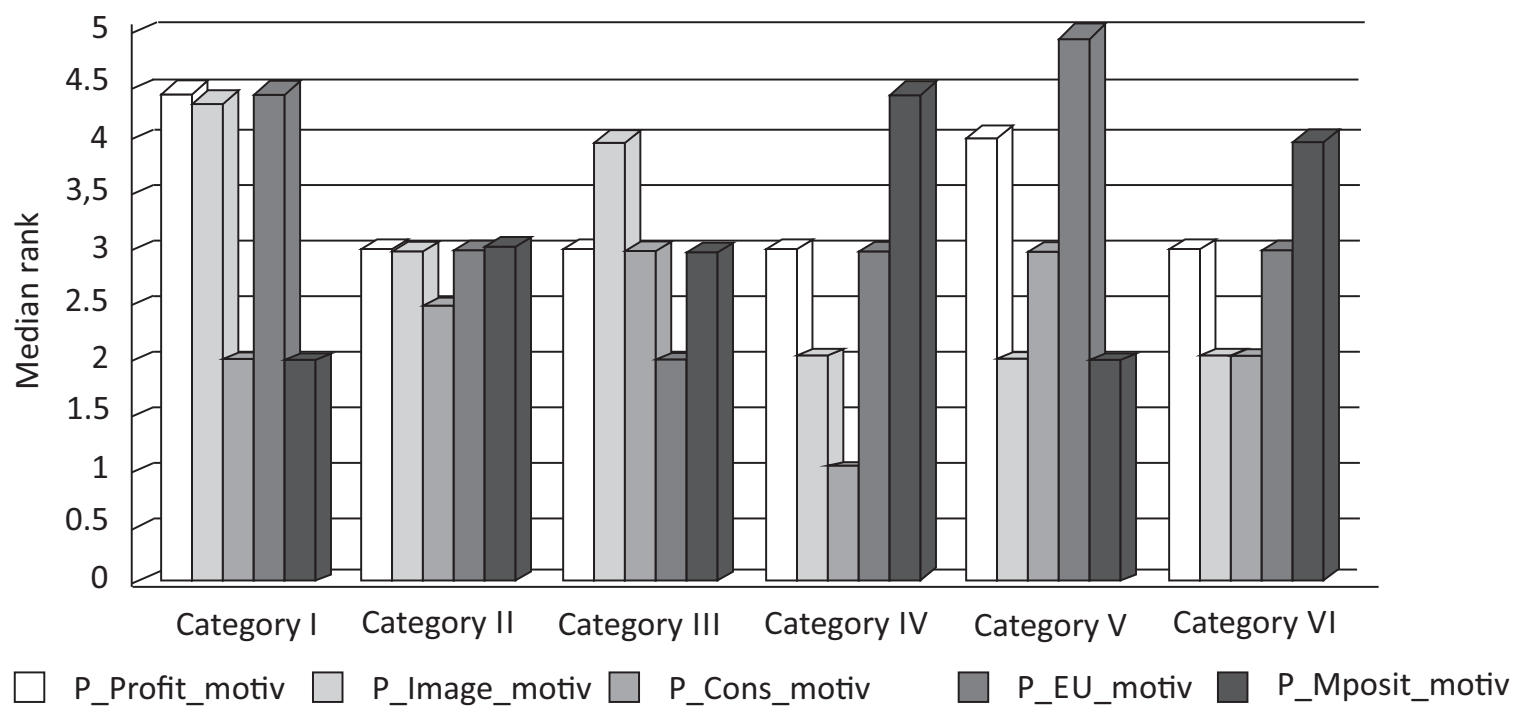

Note: Categories I-VI: jam, yogurt, milk, margarine, juice, miscellaneous

Figure 1 Producers' motivation to sell products with NHC

Source: Authors

"To improve the image of the company is the first motivation. We sell safety products with health claims and it has an influence on our consumers, their trust in our retail chain. The consumers of this category are those with a higher-income status, and we are interested in having them in our supermarkets. To answer to theconsumer's needs and get their confidence, educate customers about the health importance of products with N\&H claim, make our company a regional leader in the sales of these products" (Serbia, a retailer).

\section{Perception of demand}

The retailers ranked their responding to consumer demand as the most important motive, which is only followed by the improvement of thecompany's image. The profit motive was ranked the last. This indicates thatretailers use the studied categories as a positioning tool and do not expect high profitability from them. However, weshould be careful whendrawing conclusions on this matter, since the profits ranked the last may be caused by a socially desirable answer. Moreover, the growth of these categories will increase their contribution to the retailer's profitability. The motives of a profit and the following of the EU trends are mentioned as the least important ones. However, this does not mean that these criteria are not important. Some categories generate modest sales volumes comparing to regular products and, therefore, are not as profitable as others. However, the growth of these categories will influence the profit motivation of the companies.

The retailers point out that the main barriers for products with NHC in the WBC are consumer-related. Eating habits are the most important problem for retailers, only to be followed by consumer awareness and low demand. Consumers do not include these products in their diet and are unaware of them. This results in lower demand. The retailers do not perceive the relationship with foreign companies, logistic difficulties and the availability of products as issues of importancein the WB markets.

Generally speaking, the retailers expect an increase inconsumer demand for the NHC products in a near future. There are significant differences in the perceptions of retailers in different WBCs. Namely, retailers in Slovenia and Croatia find consumer demand to be a relatively high one; in Macedonia, 


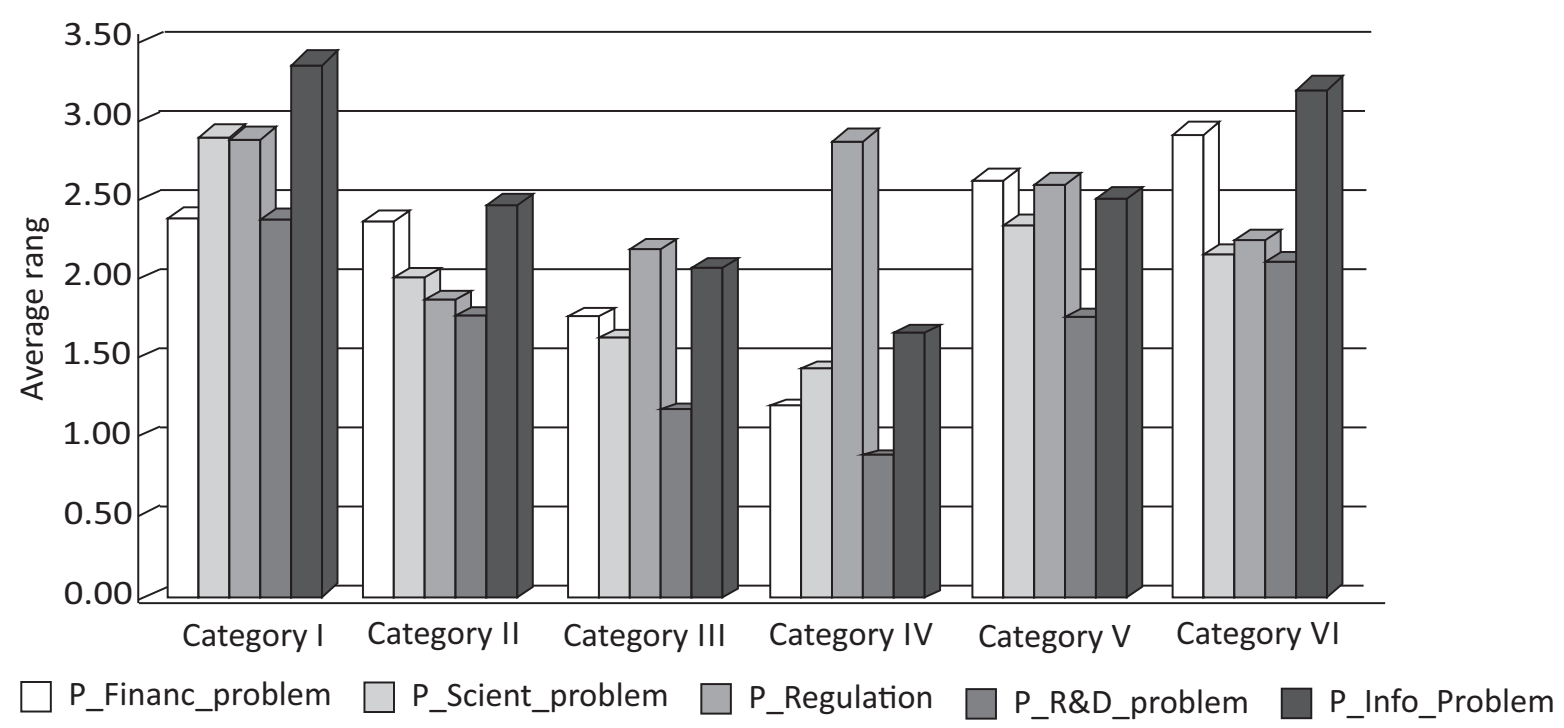

Note: Categories I - VI: jam, yogurt, milk, margarine, juice, miscellaneous

Figure 2 The perceived barriers by producers for the development of products with NHC

Source: Authors

they perceive it as moderate, while in Montenegro and Bosnia and Herzegovina,it isperceived to be at a very low level. In Serbia, consumer demandis still perceived to beinsufficient, growing and varying in the different regions of the country (it is higher in Belgrade and Vojvodina than it is in Central Serbia). On the other hand, the retailers overall agreement with the statement ofconsumer demand related to products with nutrition and health claim is high today ( from 1 for"strongly disagree"to 5 for "strongly agree") althoughlower to some extent than the one expressed by the local producers (2.82). The frequencies of answers show a similar pattern, with the most frequent mark being 3 (12 out of 28 retailers). However, only two retailers (both Slovenian) expressed theirstrong agreement with the statement (5), whereas three retailers strongly disagreed (from Serbia, Bosnia and Montenegro).

"Consumer demand for products with nutritional and health claims is growing. Until recently, these types of products were only used by individuals with health problems, but now there is a different situation. A lot of people with developed awareness about a healthy diet buy these products without having any health problems" (Macedonia, a retailer).
"Consumer demand for products with nutrition and health claims is high" (Croatia, a retailer).

"It is at avery low level, partly because of high prices, partly andrather more because of people's knowledge and their eating habits" (B\&H, a retailer).

Both producers and retailers consider health benefits to be the main influencing factor in consumers' choice of foods in all the WBCs. While the overall population is perceived to be very much price-sensitive, there is a group of consumers aware of functional food and its benefits and they are ready to pay more for it (Filipović \& Stojanović, 2012; Stojanović et al, 2013).

"It is becoming more and more important and this trend will continue in the future as well" (Serbia, a retailer).

"It is becoming more and more important. There are consumers who buya specific product thatis essential for their wellbeing regardless of its price. Also, certain consumers are quite aware of the health benefits of some food and buy products with health and nutritional claims even thoughthey don't have any health problems" (Macedonia, a retailer). 
"Health benefit is an important criterion for the consumer's choice of food - itis one of the most important criteria" (Croatia, retailer).

In general, if applied to the whole population in the WBCs, the price is seen as absolutely the most important criterion for the consumers' choice of food, however with the two exceptions: 1) concerning the product category (taste is perceived to be more important than the price in the case of margarine) and 2) concerning cross-country differences: retailers (unlike producers) in Croatia find the price to be the least important criterion in the consumers' choice of food, whereas in Macedonia, retailers ranked the safety and the health dimensions before the price.

The lack of nutritional knowledge, the price and economic difficulties are most frequently spontaneously mentioned restraints preventing theconsumer from buying a product with the NHC in all the WBCs. However, producers and retailers evaluate several other restraints to be the highly relevant ones as well, such as the lack of people's nutritional knowledge and their eating habits, with no explicit differences amongst the product categories.

"The main restraint for consumers to buy products with the H\&N claim is the price (namely their higher price)" (Croatia, a retailer).

“The lack of people's knowledge, product high prices, and most importantly - people's eating habits" (B\&H, a retailer).

"The financial situation is the most important issue" (Montenegro, a retailer).

Retailers in the WBCs generally share the same opinion as producers do: in Montenegro, they see nutrition knowledge and the price to be the most important restraints for the consumers' choice of functional food; in Serbia, these are nutrition knowledge and eating habits; in Slovenia, it is the price and the lack of nutrition knowledge; in Croatia, they refer to the economic difficulties and the price; in Macedonia, they quote the lack of nutrition knowledge and in Bosnia, it is eating habits, the economic difficulties and the availabilityof such products.
Interestingly enough, foreign exporters to the WB markets also perceive the lack of nutritional knowledge (with the exception of Slovenia) as well as the price (i.e. the economic conditions) to be the most important restraints. Sometimes, the low availability of such products in the less developed regions of the countries of the WB is mentioned. Availability isperceived to be the least important restraint among the local producers and retailers, with only a few exceptions to it.

\footnotetext{
"In a local store, one'schances to see or buy a specific product are very low. Local stores are usually supplied with ordinary products and there is not enough choice of different products" (Macedonia, a retailer).

"The low availability of products, eating habits, the economic situation, the lack of awareness ofnutritional and health values of food" (B\&H, a retailer).
}

\section{CONCLUSIONS}

The main contribution this paper makes is that it allows us to better understand the importance of products with the NHC in the WBCs. The results have confirmed the hypothesis that the NHC market in the WBCsis still underdeveloped. However, the level of its development significantly differs among the WBCs, depending on the economic development of the country. The additional hypothesis has been confirmed as well. The importance of NHC products will be increasing in the future according to all the interviewed managers. All the interviewed companies expect demand to be increasing in the long- and medium term. Currently, consumers are buyinglowerpriced products according to their purchase power. Business actors predict that the overall economic situation will improve, which will cause higher demand for products with the NHC. The improved purchasing power of the WBC consumers will be the main factor for increasing demand.

Apart from only income and the overall economic situation, people's knowledge also plays an important role in the demand change of products with the NHC. According to the interviewed representatives, people's education has to start in elementary school due to the bad eating habits of the population. Accepting 
changing lifestyles is also an important factor for thedevelopment of products with the NHC. The producers also pointed out the importance of the following EU trends as a factor that would influence the consumption of functional foods. However, inthe interviewees' opinions, the WB region lags five or more years behind the EU trends. Although the interviewed producers appear to be completely ready to develop the market of products with the NHC, they also consider that consumers are still unready for them. On the other hand, the exporters expect that the sales growth of functional food in the WBCs will be higher than the one in the EU markets.

Healthy products are usually recognized as an "umbrella" for different kinds of product categories (e.g. "natural products" - without preservatives or artificial additives; or even organic products). Although the interviewees do not think that these products are only oriented towards people with health problems, it is often suggested that the health status of a population might be an important factor shaping the consumer's demand trend in the future. Evidently, issues such as health, children's obesity and sustainability globally draw more attention and concerns. Consequently, governments will focus on health and sustainability. Furthermore, improved communication will also affect a future rise in the sale of functional foods.

The retailers pointed out the importance of cooperation between the sector stakeholders in the development of the NHC products market. In the countries where NHC trade labels are not developed, retailers feel that producers should lead this process. They also think that domestic companies are not significantly motivated to offer these products to the market. Nevertheless, retailers' opinions slightly differ regarding the main factors of change in demand for products with the NHC. The most important factors of change are related to people's nutritional knowledge, their education and the public-policy-related activities in the domain of the promotion of healthier lifestyles in the WBC region. The fashion and consumers' purchase power are evaluated significantly less important. Consumers mostly purchase functional foods in hypermarkets and supermarkets, dominantly present in the urban, developed regions of their respective countries. The specific target population is more highlyeducated and with higher income than an average one.

Consequently, in the future, a significant involvement of retailers in the process of the launching of new functional food products can be anticipated to take place. The rapid development of trademarks and aneed to be competitive in the market not only in terms of prices but also in terms ofthe quality and the product range is what forces retailers to consider launching their own brands for products with the NHC. Given the fact that a growth of trademarks in the subject product category is expected, this trend will be rather salient in the WBCs.

Ultimately, it should be mentioned that the producers suggest that the amount of products with the NHC will be limited or even reduced due to the new legislation in the EU and the absence of a governmental support in this field. They also argue that consumer trust towards products with health claims is an important factor. The development of these products might be strongly correlated with the regulation of nutrition and health claims. Nutrition claims are regulated in all Balkan countries and health claims are only regulated in Slovenia and have recently been regulated in Croatia. Once having been introduced, regulationhas to be properly applied. It is very important that the claims shouldnot be misleading consumers. From the producers' point of view, there is no national nutritionrelated policy, which stands for one of the strongest barriers hindering a future development of this market. Regulation needs to be improved and clearly communicated to producers.

The functional food market is still a young market, being present in the WBCs for barely a decade. However, its rapid growth and the constant increase inthe number of people consuming products with the $\mathrm{NHC}$ - globally, in the EU and in the WBCs - request our better comprehension and further investigation of the consumers of functional foods in order to enable more effective marketing targeting, more profitable business and anenhancement of the health status of the local population.

Due to very little relevant research and data on the subject, the results of this qualitative research have 
made a contribution to thebetter understanding of marketing strategies when products with the NHC in the WBCs are concerned.

The research, however, has its limitations. This is a qualitative research: therefore, a quantitative dimension is lacking. In addition to this, the sample is dominated by the medium- and large manufacturing and retail companies. It is also limited to the five product categories.

Future researches should focus on overcoming the above-mentioned limitations. Conducting quantitative researches of manufacturers and retailers as well as consumers would help obtain an accurate picture of the size and importance of the aforementioned market. It is necessary that small producers and retailers be included in the study because their perspective is also very important. To add, it would be interesting to research a larger number of theNHC product categories.

\section{ACKNOWLEDGEMENTS}

The research leading to these results has received funding from the European Union's Seventh Framework Programme (FP7 2007-2013) under grant agreement 212579.

\section{REFERENCES}

Caswell, J. A., \& Padberg, I. D. (1992). Toward a More Comprehensive Theory of food Labels. American Journal of Agricultural Economics, 74(2), 460-468.

Caswell, J. A., \& Mojduszka, E. M. (1996). Using Informational Labeling to Influence the Market for Quality in Food Products. American Journal of Agricultural Economics, 78(5), 1248-1253.

Caswell, J. A., \& Johnson G. V. (1991). Firm Strategic Response to Food Safety and Nutrition Regulation. In J. A. Caswell (Ed.), Economics of Food Safety (pp. 273-297). New York: Elsevier Science Publishing Co.

Christidis, N., Tsoulfa, G., Varagunam, M., \& Babatzimopoulou, M. (2011). A cross sectional study of consumer awareness of functional foods in Thessaloniki, Greece. Nutrition \& Food
Science, 41(3), 165-174.

Dimić, E. B., Vukša, V. L., \& Dimić, V. (2002). Margarin i masni namazi kao funkcionalna hrana. Uljarstvo, 33(3-4), 3-8.

Dimitrijević-Branković, S. I., Baras, J. K., \& Bojović, J. (2002). Značaj i mogućnosti proizvodnje funkcionalne hrane. Hemijska industrija, 56(3), 113-122.

Diplock, A. T., Agget, P. J., Ashwell, M., Bornet, F., Fern, E. B., \& Roberfroid, M. B. (1999) Scientific concepts of functional foods in Europe: consensus document. British Journal of Nutrition, 81(1), S1-S27.

Euromonitor. (2012). Fortifiedlfunctional packaged food: market sizes. London: Euromonitor International

Filipović, J., \& Stojanović, Ž. (2012). Serbian consumer acceptance of functional foods: sociodemographic and attitudinal determinants. In V. Babić (Ed.), Contemporary Issues in Economics, Business and Management (pp. 179-188), Kragujevac: Faculty of Economics University of Kragujevac.

Grujić, R. (2005). Food Labeling. In Grujić, R., \& V. Sanchis (Eds.) Proceedings of Final TEMPUS Seminar (pp. 105-120), Banja Luka.

Heasman, M., \& Mellentin, J. (2001). The Functional Foods Revolution: Healthy People, Healthy Profits? London: Earthscan Publications.

Hojoon, C., Kyunga, Y., Tae, H. B., Reid, L. N., \& Macias, W. (2013). Presence and effects of health and nutrition-related (HNR) claims with benefit-seeking and risk-avoidance appeals in female-orientated magazine food advertisements. International Journal of Advertising, 32(4), 587-616.

Kapsak, W. R., Rahavi, E. B., Childs, N. M., \& White, C. (2011). Functional Foods: Consumer Attitudes, Perceptions, and Behaviors in a Growing Market. Journal of the American Dietetic Association, 111(6), 804-810.

Koch, V., \& Pokorn, D. (1999). Comparison of nutritional habits among various adult age groups in Slovenia. Nutritional Research, 19(8), 1153-1164.

Ljaljević A., Durišić B., Mališić N., \& Ivanović Lj. (2006). The volume of nutrition elements from milk and eggs in the acerage daily nutrition of the Montenegrin population compared to the recommended daily nutrition components volume. Podgorica: Institute for public health of Montenegro.

Markovina, J., Čačić, J., Kljusurić, J. G., \& Kovačić, D. (2011). Young consumers' perception of functional foods in Croatia. British Food Journal, 113(1), 7-16.

Miletić, I., Šobajić, S., \& Đorđević, B. (2008). Funkcionalna 
hrana - uloga u unapređenju zdravlja. Journal of Medical Biochemistry, 27(3), 367-370.

Patel, A. (2012). The regulation of health and nutrition claims for the promotion of food. International Journal of Management Cases, 14(1), 340-346.

Raspor, P., \& Jevsnik, M. (2008). Good Nutritional Practice from Producer to Consumer. Food Science and Nutrition, 48(3), 276-292.

Ristevska-Jovanovska, S. (2007). Промени во заштитата на потрошувачите во ЕУ согласно со програмата 2007-2013 и состојбите во Република Македонија. Annual of the Faculty of Economics, 42, 39-48

Ristić, G. (2003). Funkcionalna hrana - hrana za XXI vek. Mlekarstvo, 2(14), 428-433.

Rogelj, I. (2000). Funkcionalna hrana - hrana budućnosti,
Prehrambena industrija. Mleko i mlečni proizvodi, 11(1-2), 4042

Stanković, I. M. i Đorđević, B. I. (2002). Funkcionalna i nekonvencionalna hrana - zakonska regulativa. Hrana $i$ ishrana, 43(1-2), 60-62.

Stojanović, Ž., Dragutinović-Mitrović, R., \& Zaouche-Laniau, M. (in press). Products with nutrition and health claims in the Western Balkans: labelling behaviour, regulation and policy implications. European Journal of Law and Economics.

Stojanović, Ž., Filipović, J., \& Mugoša, B. (2013). Consumer acceptance of functional foods in Montenegro. Montenegrin Journal of Economics, 9(3), 65-74.

Šobajić, S. (2002). Funkcionalna hrana u prevenciji bolesti i terapiji. Arhiv za farmaciju, 52(3), 369-375.

$$
\begin{array}{r}
\text { Received on } 17^{\text {th }} \text { March 2014, } \\
\text { after revision, } \\
\text { accepted for publication on } 17^{\text {th }} \text { April } 2014 .
\end{array}
$$

Zaklina Stojanovic is a professor employed at the Faculty of Economics of Belgrade University. She teaches Agricultural Economics in the undergraduate studies and gives lectures related to agro-rural courses in the Economic Policy and Development master's program and the Economics PhD program. She has edited six and has written as the author three books as well as more than 100 articles in agricultural economics, rural development and agricultural finance.

Jelena Filipovic is an assistant professor of Marketing Communications and Services Marketing at the Faculty of Economics of Belgrade University. Her research interest includes Internet communications, children as consumers and the marketing of food products. She has published articles in the International Marketing Review, Communications and Strategies, Ekonomika poljopriorede.

Dragan Stojkovic is an assistant professor at the Faculty of Economics of Belgrade University. He teaches the following courses: Marketing Channels, Trade Marketing and Sales Management, E-commerce. His research focus includes: retail marketing and management, e-commerce. He has published articles in both international and domestic scientific publications. 


\title{
TRŽIŠTA HR ANE SA NUTRITIVNOM I ZDRAVSTVENOM IZJAVOM: PERSPEKTIVE PROIZVOĐAČA I MALOPRODAVACA
}

\author{
Žaklina Stojanović, Jelena Filipović*, Dragan Stojković \\ Ekonomski fakultet Univerziteta u Beogradu
}

Tržište proizvoda sa nutritivnom i zdravstvenom izjavom u zemljama Zapadnog Balkana postoji nešto više od decenije, ali je do sada ostalo skoro u potpunosti neistraženo. Zbog toga je cilj ove studije da kroz kvalitativna istraživanja utvrdi značaj proizvoda sa nutritivnom i zdravstvenom izjavom u ovom regionu. $\mathrm{U}$ radu se analiziraju cene i marže predmetne grupe proizvoda, kanali distribucije, percepcija trendova tražnje i podsticaji i barijere za budući razvoj tržišta funkcionalne hrane. Istraživanje je obuhvatilo pet kategorija proizvoda sa nutritivnom i zdravstvenom izjavom, a korišćena je tehnika dubinskog intervjua. U istraživanju je učestvovalo 29 proizvođača i 26 maloprodavca sa područja šest država Zapadnog Balkana. Iako sve analizirane kategorije beleže rast prodaje u prethodnom periodu, značajnije povećanje se očekuje u srednjem i dužem roku, sa rastom životnog standarda stanovništva, s obzirom na to da ove proizvode karakteriše veća cena od regularnih. Rezultati istraživanja upućuju da je potrebna edukacija stanovništva o ulozi hrane u očuvanju zdravlja, kao i menjanje loših navika u ishrani. Razvoj tržišta funkcionalne hrane zahteva i državnu podršku i odgovarajuću zakonsku regulativu.

Ključne reči: funkcionalna hrana, nutritivna izjava, zdravstvena izjava, tržišta Zapadnog Balkana

JEL Classification: D12, 115, M38

\section{UVOD}

Iako je istraživanje zdravstvenih i nutritivnih tema već dugo prisutno u medicinskim i prirodnim naukama, zdrav način života počinje da se izučava tek krajem XX-og veka. U poslednjih nekoliko decenija, i tržišna i akademska istraživanja nedvosmisleno ukazuju na

\footnotetext{
* Korespondencija: J. Filipović, Ekonomski fakultet Univerziteta u Beogradu, Kamenička 6, 11000 Beograd, Srbija; e-mail: jfilipovic@ekof.bg.ac.rs
}

povećanje svesti potrošača i njihove zainteresovanosti za zdravstvena pitanja, a posebno za namirnice sa nutritivnim i zdravstvenim (NiZ) izjavama (Kapsak, Rahavi, Childs \& White, 2011; Hojoon, Kyunga, Tae, Reid \& Macias, 2013). U oblasti društvenih nauka ekonomije, marketinga, psihologije i dr., studije koje za temu imaju hranu sa NiZ izjavama počinju da se sprovode od 1990-ih.

Neophodno je napomenuti da hrana sa NiZ izjavama nije sasvim definisana kategorija. U većini zemalja ne 
postoji zakonska definicija ove grupe namirnica, mada pregled literature pokazuje da je etiketiranje hrana sve važnije polje istraživanja (Caswell \& Johnson, 1991; Caswell \& Padberg, 1992; Caswell \& Mojduszka, 1996; Heasman \& Mellentin, 2001; Patel, 2012). Iako je ova vrsta hrane već prisutna i prepoznata u zemljama Zapadnog Balkana (ZB), većina potrošača nije upoznata sa tačnim značenjem termina „funkcionalna hrana". Istraživanje mladih u Hrvatskoj (Markovina, Čačić, Kljusurić \& Kovačić 2011) otkrilo je da je samo 39,4 odsto ispitanika bilo upoznato sa navedenim pojmom, mada se tri četvrtine njih izjasnilo da su kupci funkcionalne hrane kada im je data definicija iste. Od onih koji su kupci funkcionalne hrane, njih 26,8\%, $51,5 \%, 22,1 \%$ kupuje ovu hranu redovno, povremeno, retko, respektivno.

Generalno prihvaćena definicija (Diplock, Agget, Ashwell, Bornet, Fern \& Roberfroid, 1999) opisuje funkcionalnu hranu kao hranu koja „utiče blagotvorno na jednu ili više ciljnih funkcije tela, izvan uobičajenih nutritivnih efekata, na način koji je relevantan ili za poboljšanje stanja zdravlja i blagostanja ili/i za smanjenje rizika od bolesti". Na jednostavniji način rečeno, funkcionalna hrana (hrana sa NiZ izjavom) jeste ona koja može da unapredi zdravlje i umanji rizik od bolesti (Christidis, Tsoulfa, Varagunam \& Babatzimopoulou, 2011).

Prva hipoteza koja se ispitu u ovom radu je da tržište proizvoda sa NiZ izjavom nije dovoljno razvijeno na prostoru ZB. Dodatna hipoteza je da će se važnost ovog tržišta značajno povećati u budućnosti.

Za ispitivanje navedenih hipoteza korišćena je tehnika dubinskog intervjua, dok su uzorak činili vodeći proizvođači i maloprodavci sa prostora ZB.

U zemljama ZB malo je pažnje posvećeno istraživanju proizvoda sa NiZ, kako iz perspektive potrošača, tako i iz perspektive proizvođača. Analiza regulatornog okvira, kao i medicinskih i tehnoloških aspekata, prisutna je na elementarnom nivou. Značajna većina radova o proizvodima sa NiZ izjavama u zemljama ZB objavljena je $u$ medicinskim i poljoprivrednim časopisima, uobičajeno od strane autora sa medicinskim obrazovanjem (Koch \& Pokorn, 1999; Ristevska-Jovanovska, 2000; Šobajić, 2002; Miletić,
Šobajić i Đorđević, 2008). U nekolicini teorijskih radova naglašavaju se zdravstvene koristi od potrošnje funkcionalne hrane ili se analiziraju pravno okruženje i propisi u vezi ovog tipa hrane (Stanković i Đorđević, 2002; Grujić, 2005; Raspor \& Jevsnik, 2008).

Dalje, nekoliko autora analizira mogući doprinos marketinga i tehnologije boljoj ponudi hrane sa NiZ izjavama (Rogelj, 2000; Dimitrijević-Branković, Baras i Bojović, 2002; Dimić, Vukša i Dimić, 2002; Ristić, 2003; Ljaljević, Durišić, Mališići I Ivanović, 2006). Ž. Stojanović, R. Dragutinović-Mitrović i M. Zaouche-Laniau (2013) izveštavaju o rezultatima provere dostupnosti proizvoda sa NiZ izjavama u prodavnicama šest država regiona $(\mathrm{BiH}$, Hrvatska, Makedonija, Crna Gora, Republika Srbija i Slovenija). Provera dostupnosti ovih proizvoda u supermarketima, hipermarketima i prodavnicama zdrave hrane pokazuje da su na tržištu prisutna 475 proizvoda koja se uklapaju u prihvaćenu definiciju proizvoda sa NiZ izjavom (Diplock et al, 1999). Tri četvrtine tih proizvoda pronađeno je $u$ super/hipermarketima, a skoro dve trećine istih bilo je ZB porekla. U skladu sa situacijom prisutnom na razvijenim tržištima (Euromonitor, 2012), prisustvo ovih proizvoda najveće je u sektoru mlečnih proizvoda (na primer, probiotski jogurt). Cilj našeg istraživanja i rada jeste upoznavanje i razumevanje tržišta proizvoda sa NiZ izjavom na području ZB.

\section{METODOLOŠKI OKVIR ANALIZE}

U istraživanju je korišćena tehnika dubinskog intervjua, koja predstavlja jedan od vidova kvalitativnog istraživanja. Kvalitativne tehnike uobičajeno se koriste kod eksploratornih istraživanja, gde je težište na otkrivanju ideja, boljem razumevanju izučavanog problema i postavljanju hipoteza za buduća istraživanja iz istog domena.

Tehnika dubinskog intervjua omogućava detaljnije razumevanje ponašanja, stavova, motiva, itd, kao i prikupljanje velikog broja informacija $\mathrm{u}$ relativno kratkom vremenskom intervalu. Intervjue su sprovodila obučena lica, gde je svaki u proseku trajao oko jednog časa. Upitnik je sadržao otvorena pitanja, dok je u pojedinim slučajevima bio dat spisak mogućih 
odgovora, tako da se može produbiti diskusija o različitim temama. Izbor proučavanih kategorija proizvoda izvršen je na bazi prethodnog pregleda prodavnica u svakoj od zemalja ZB.

U fokusu istraživanja bile su sledeće kategorije proizvoda sa NiZ izjavom:

- dijetetski džem (džem za osobe koje boluju od dijabetesa),

- mleko obogaćeno vitaminima i mineralima,

- jogurt sa probioticima,

- niskokalorični margarin,

- sokovi i nektari obogaćeni vitaminima i mineralima.

U Tabeli 1 predstavljene su osnovne karakteristike ispitivanih kategorija proizvoda. Proizvođači i malporodavci su izabrani prema njihovom značaju na tržištu proizvoda sa NiZ izjavom na nacionalnom nivou. Ispitanici su u većini slučajeva bili marketing menadžeri i menadžeri ispitivanih kategorija proizvoda. Imajući u vidu da su učesnici izabrani u skladu sa prethodno određenim kriterijumima, mišljenja koja su izrazili $u$ dubinskim intervjuima treba smatrati tipičnim za taj segment tržišta. Većina intervjuisanih proizvođača bavi se proizvodnjom mlečnih proizvoda, preradom voća ili proizvodnjom ulja, a uglavnom dolaze iz srednjih i velikih preduzeća. U studiji je ukupno intervjuisano 29 proizvođača i 26 maloprodavaca, sa teritorije celog ZB. Intervjuisanje je sprovedeno 2011. godine. U okviru toga, većina kompanija-ispitanika predstavljaju lidere $\mathrm{u}$ ispitivanim kategorijama u svojim zemljama. Samim tim, može se smatrati da su intervjuisani proizvođači reprezentativni za istraživane kategorije. Ispitivani maloprodavci su trgovci koji prodaju pretežno prehrambene proizvode i koji svoje poslovanje zasnivaju na klasičnim formatima koji se javljaju $\mathrm{u}$ prehrambenoj maloprodaji, a to su su pre svega supermarketi, hipermarketi, superete i mini-marketi.

\section{EMPIRIJSKI REZULTATI}

Tržište ispitivanih kategorija proizvoda zemalja
Tabela 1 Osnovne karakteristike kategorija proizvoda uključenih $\mathrm{u}$ anketiranja

\begin{tabular}{|c|c|c|c|}
\hline Kategorija & Proizvodi & Izjave & $\begin{array}{l}\text { Specifičnost } \\
\text { proizvoda }\end{array}$ \\
\hline $\begin{array}{l}\text { Džem za } \\
\text { osobe koje } \\
\text { boluju od } \\
\text { dijabetese }\end{array}$ & $\begin{array}{l}\text { Džem } \\
\text { zaslađen } \\
\text { fruktozom } \\
\text { ili zajedno } \\
\text { fruktozom i } \\
\text { zaslađivačima }\end{array}$ & $\begin{array}{l}\text { „Prikladan za } \\
\text { osobe koje } \\
\text { boluju od } \\
\text { dijabetesa” } \\
\text { „Dijetalan”, } \\
\text { sa 30\% manje } \\
\text { kalorija }\end{array}$ & $\begin{array}{l}\text { Smanjena } \\
\text { kaloričnost } \\
\text { (30\% ili 50\%), } \\
\text { dijetetski }\end{array}$ \\
\hline $\begin{array}{l}\text { Jogurt sa } \\
\text { probiotikom }\end{array}$ & $\begin{array}{l}\text { Jogurt sa } \\
\text { posebnim } \\
\text { „probiotičkim } \\
\text { fermentima” }\end{array}$ & $\begin{array}{l}\text { „Povoljan } \\
\text { uticaj na } \\
\text { varenje; } \\
\text { stimuliše } \\
\text { metabolizam” }\end{array}$ & $\begin{array}{l}\text { Posebni } \\
\text { fermenti } \\
\text { zajedno sa } \\
\text { uobičajenim } \\
\text { fermentima } \\
\text { u jogurtu; } \\
\text { funkcionalna } \\
\text { izjava }\end{array}$ \\
\hline $\begin{array}{l}\text { Mleko } \\
\text { obogaćeno } \\
\text { vitaminima i } \\
\text { mineralima }\end{array}$ & $\begin{array}{l}\text { Mleko } \\
\text { obogaćeno } \\
\text { kompleksom } \\
\text { vitamina i } \\
\text { minerala }\end{array}$ & $\begin{array}{l}\text { Vitamini A,D, } \\
7 \text { vitamina, } \\
\text { Ca+ }\end{array}$ & $\begin{array}{l}\text { I regularno i } \\
\text { niskomasno } \\
\text { mleko; } \\
\text { funkcionalna } \\
\text { izjava }\end{array}$ \\
\hline $\begin{array}{l}\text { Niskomasni } \\
\text { margarin }\end{array}$ & $\begin{array}{l}\text { Margarin } \\
\text { sa značajno } \\
\text { sniženim } \\
\text { sadržajem } \\
\text { masti }\end{array}$ & $\begin{array}{l}\text { „Dijetalni“ } \\
25 \% \text { masti }\end{array}$ & $\begin{array}{l}\text { Smanjen } \\
\text { sadržaj } \\
\text { masti; } \\
\text { funkcionalna } \\
\text { izjava }\end{array}$ \\
\hline $\begin{array}{l}\text { Nektari i } \\
\text { voćni sokovi } \\
\text { obogaćeni } \\
\text { vitaminima }\end{array}$ & $\begin{array}{l}\text { Nektari i } \\
\text { voćni sokovi } \\
\text { obogaćeni } \\
\text { raznim } \\
\text { vitaminima i } \\
\text { dodacima }\end{array}$ & $\begin{array}{l}\text { Multivitamin, } \\
\text { 100\% voćni } \\
\text { sok, dodati } \\
\text { vitamini, } \\
\text { Sadrži } \\
\text { vitamine }\end{array}$ & $\begin{array}{l}\text { Dodati } \\
\text { vitamini ili } \\
\text { sastojci; } \\
\text { funkcionalna } \\
\text { izjava }\end{array}$ \\
\hline
\end{tabular}

Izvor: Autori

ZB značajno je evoluiralo $\mathrm{u}$ poslednje tri godine, a posebno u Republici Srbiji, Makedoniji i $\mathrm{BiH}$. Međutim, postoje i određene razlike među ispitivanim kategorijama i zemljama. Stope rasta pojedinih proizvoda su veoma visoke, jer su neki od njih tek nedavno predstavljeni na tržištu. U principu, sve ispitivane kategorije beleže povećanje prodaje $u$ poslednje tri godine na ZB tržištu. Na razvijenijim tržištima imaju niže stope rasta, jer su ona više zasićena, kao što je i svesnost potrošača na 
višem nivou $u$ ovim zemljama. $U$ manje razvijenim zemljama $\mathrm{ZB}$, stope rasta su veće i taj trend se očekuje i u budućnosti. Očekuje se da će sve više potrošača prihvatati proizvode sa NiZ oznakom sa rastom životnog standarda i rastom obrazovanja potrošača.

\section{Cena}

Po pitanju cena, može se primetiti da proizvođači naplaćuju veće cene za skoro sve proučavane kategorije (osim za niskomasni margarin). Međutim, to ne znači da oni naplaćuju veću maržu za sve proizvode, s obzirom na to da je proizvodni proces za neke od proizvoda sa NiZ izjavom skuplji nego za redovne proizvode. Shodno tome, cena tih proizvoda je veća. Na primer, proizvodnja džema za osobe koje boluju od dijabetesa je skuplja od redovne proizvodnje džema zato što se umesto šećera koristi fruktoza i veći je sadržaj voća. Pored toga, brendirani uvozni džemovi iz EU su prisutni na ZB tržištima. Maloprodavci naplaćuju istu maržu za proizvode sa i bez NiZ izjave u svim ispitanim kategorijama.

Mlečni sektor je prilično heterogen sa stanovišta određivanja marži proizvoda sa NiZ izjavom. Proizvođači jogurta sa probioticima tvrde da ne naplaćuju veće marže, međutim većina njih navodi da je cena ovog jogurta veća u odnosu na cenu običnog jogurta. Objašnjenje je da je proizvodnja jogurta obogaćenog probioticima skuplja (uključuje specifične fermente). Dalje, većina proizvođača se slaže da je cena mleka obogaćenog vitaminima i mineralima veća od cene redovnog mleka. Međutim, polovina anketiranih proizvođača tvrdi da naplaćuje isti nivo marže kao i za redovno mleko. Samo nekoliko proizvođača navodi da naplaćuje veće marže za ovaj proizvod, a jedan proizvođač čak tvrdi da naplaćuje nižu maržu za ovu vrstu mleka. Zaključuje se da je politika marži najmanje uniformna $\mathrm{u}$ ovoj kategoriji proizvoda $\mathrm{u}$ odnosu na sve proučavane. Većina proizvođača dijetalnih (niskomasnih) margarina tvrde da oni naplaćuju iste marže kao i za obične margarine. Međutim, podaci pokazuju da se cene razlikuju u odnosu na cene redovnih margarina. Cena niskomasnog margarina je obično niža od cene tradicionalnog margarina zbog smanjenog sadržaja ulja.
Većina ZB proizvođača nektara obogaćenih vitaminima i mineralima tvrde da oni ne naplaćuju veće marže u odnosu na njihove ostale sokove. Samo je nekolicina proizvođača izjavila da oni naplaćuju veće marže za ove proizvode. Ipak, većina njih priznaje da su cene ovih sokova veće $u$ odnosu na cene redovnih sokova. Više cene se mogu objasniti većim maržama, ali i dodatnim troškovima obogaćivanja soka sa vitaminima.

Opšti je zaključak da su cene proizvoda sa NiZ izjavama veće od cena regularnih proizvoda zbog skupljih procesa proizvodnje. Jedini izuzetak je dijetalni margarin koji je jeftiniji od običnog margarina.

\section{Kanali distribucije}

Kanali distribucije za istraživane kategorije relativno su slični standardnim kanalima distribucije za prehrambene proizvode na tržištima ZB. Ipak, postoje određene razlike među kategorijama i zemljama.

Zemlje ZB imaju različite nivoe razvijenosti kanala distribucije. Slovenija ima najrazvijenije kanale distribucije, koji su slični onima u razvijenim zemaljama EU. Moderni maloprodajni formati poput hipermarketa i supermarketa su dominantni na ovom tržištu i učestvuju sa preko $75 \%$ u maloprodaji hrane. Pored toga, maloprodajni lanci drže više od $80 \%$ maloprodajnog prehrambenog tržišta. Hrvatska, takođe, ima razvijeniju maloprodajnu strukturu od ostalih zemalja ZB, gde moderni maloprodajni formati čine $50 \%$ tržišta, uz značajan udeo maloprodajnih lanaca. Republika Srbija i Bosna i Hercegovina, takođe, imaju značajan udeo maloprodajnih lanaca u maloprodaji hrane, čiji je udeo manji na tržištima Makedonije i Crne Gore. U ovim zemljama je značajnija uloga malih i privatnih prodavnica. Ipak, male prodavnice imaju ograničen asortiman i prodaju proizvode sa najvećim obrtom. Proizvodi sa NiZ izjavom uglavnom ne ispunjavaju ovaj kriterijum.

Glavni kanal distribucije džemova za osobe koje boluju od dijabetesa su maloprodajni lanci. U proseku se više od $70 \%$ prodaje obavi u maloprodajnim lancima, naročito $\mathrm{u}$ supermarketima i hipermarketima. Ovaj proizvod obično stoji u sekciji "Zdrava hrana" ili u posebno odvojenim policama na kojima se nalazi 
hrana za dijabetičare. U manje razvijenim zemljama, uloga malih prodavnica je značajnija u prodaji hrane, ali ove prodavnice obično ne drže dijetetske proizvode, ili nude ograničen broj proizvoda. U nekim zemljama, poput Srbije, specijalizovane prodavnice zdrave hrane takođe učestvuju u prodaji ove kategorije. Pored toga, određen procenat prodaje ostvaruje se kroz veleprodajne kanale. Distribucija kroz institucionalne kupce, poput bolnica, je značajan kanal u Sloveniji, kao i u nekim drugim zemljama. Ovaj proizvod se, takođe, može pronaći u apotekama i drogerijama.

„Trenutni potrošački trend je orijentisanost prema supermarketima. Ovo važi za svaku kategoriju proizvoda. Uopšteno, analitički podaci na globalnom nivou pokazuju da se najveći obrt postiže u maloprodajnim lancima. Niihova prednost je $\mathrm{u}$ tome što se većina stvari može pronaći na jednom mestu, $u$ jednom supermarketu. $S$ druge strane, prednost drugih kanala distribucije, poput specijalizovanih prodavnica dijetetskih proizvoda je da je potrošač u stanju da dobije direktne informacije i objašnjenja o proizvodu koji žele da kupe. Ali, tu nema visokog obrta, a druga stvar je da male radnje ne mogu da se takmiče sa cenama" (Makedonija, proizvođač).

Zaključuje se da će maloprodajni lanci i velike prodavnice, poput hipermarketa i supermarketa, dominirati na tržištima $\mathrm{ZB} u$ ovoj kategoriji $u$ budućnosti; mada se i u manjim formatima, naročito kod objekata koji su u sastavu maloprodajnih lanaca mogu naći navedeni proizvodi.

Slično kao $\mathrm{u}$ prethodnoj kategoriji proizvoda, maloprodajni lanci su najvažniji kanal prodaje jogurta sa probioticima. Maloprodajni lanci čine $75 \%$ prodaje ove kategorije za većinu prerađivača. Pored toga, više od polovine ispitanih mlečnih prerađivača prodaje kroz samo jedan maloprodajni lanac. Supermarketi i hipermarketi su vodeći prodajni formati i za ovu kategoriju proizvoda. Ipak, mini marketi su važni, naročito u manje razvijenim zemljama. U Crnoj Gori se, na primer, $75 \%$ prodaje ove kategorije obavi u mini marketima. Treba naglasiti da male prodavnice nemaju dovoljno rashladnih polica i da nude ograničen asortiman proizvoda koji moraju da se hlade. Prerađivači prodaju preko veleprodavaca, naročito na manje razvijenim tržištima ZB. Obično je jeftinije doći do malih prodavnica kroz veletrgovce.
Male prodavnice imaju ograničene asortimane, i često ne drže proizvode sa NiZ izjavom. Ipak, kroz marketinške napore prerađivača, sitni maloprodavci su ponekad spremni da u svoj asortiman uključe i jogurte sa probioticima, naročito u urbanim područijima. Ovaj proizvod se takođe prodaje i u pekarama. Svi ispitanici tvrde da će maloprodajni lanci ostati glavni kanal distribucije i u budućnosti, sa većim udelom hipermarketa i supermarketa.

Najmanje $75 \%$ prodaje mleka obogaćenog vitaminima i mineralima ostvareno je kroz maloprodajne lance. Hipermarketi i supermarketi su dominantni u ovoj kategoriji. Veletrgovci i male prodavnice su značajni u manje razvijenim zemljama i regionima. Međutim, oni nude ograničen asortiman mlečnih proizvoda i obično nabavljaju samo obično mleko.

„U malim prodavnicama, ne postoje police za takve specifične proizvode" (Slovenija, proizvođač).

„Hipermarketi postaju sve značajniji za nas" (Bosna i Hercegovina, proizvođač).

Značaj maloprodajnih lanaca će porasti za ovu kategoriju, dok proizvođači očekuju da će hipermarketi biti najbrže rastući format u zemljama ZB.

Maloprodajni lanci dominiraju i $u$ kategoriji niskomasnog margarina. Ispitani proizvođači ostvarili su oko $85 \%$ prodaje putem maloprodajnih lanaca. Supermarketi i hipermarketi generišu većinu prodaje. Minimarketi su učestvovali sa $30 \%$ u prodaji maloprodajnih lanaca. Proizvođači prodaju oko $15 \%$ niskomasnog margarina preko veletrgovaca $u$ Hrvatskoj i Republici Srbiji. Ovaj procenat bi mogao biti još i veći u manje razvijenim zemljama ZB. Hoteli i restorani su, takođe, zanimljivi kanali prodaje niskomasnog margarina, naročito u zemljama sa jakom turističkom industrijom. Pored toga, za margarin su neophodni frižideri, što podrazumeva veće troškove, tako da su male prodavnice vrlo obazrive pri izboru proizvoda koji moraju da se hlade.

„Najvažniji su maloprodajni lanci - hipermarketi i supermarketi. Male prodavnice ne zahtevaju stalno snabdevanje ovim proizvodima. Oni su zainteresovani za proizvode bez životinjske masti tokom perioda kada se posti. Ljudi u malim prodavnicama kupuju samo vodeće brendove. U velikim prodavnicama su 
zainteresovani za cenu, kvalitet, i voljniji su da kupe naš proizvod“ (Republika Srbija, proizvođač).

Maloprodajni lanci će dominirati u budućnosti. Ipak, širenje turističke industrije bi moglo da utiče na to da hoteli i restorani postanu značajan kanal.

Maloprodajni lanci su najvažniji kanal distribucije i za kategoriju sokova obogaćenih vitaminima i mineralima. Ipak, procenat prodaje koja se obavi kroz maloprodajne lance je manji nego za druge kategorije. Veletrgovci su bitniji u ovoj kategoriji u poređenju sa ostalim istraživanim kategorijama. Zbog toga male prodavnice imaju veći značaj, naročito u manje razvijenim zemljama i manje razvijenim regionima određenih zemalja. Pored toga, HORECA segmet je bitan za ovu kategoriju. Maloprodajni lanci donose $50 \%$ prodaje u ovoj kategoriji.

„Mi ne distribuiramo direktno, imamo distributera koji to čini za nas. Supermarketi i hipermarketi će postati važniji za nas u budućnosti" (Republika Srbija, proizvođač).

„Ova kategorija proizvoda se distribuira preko maloprodajnih lanaca i malih prodavnica, ali imamo značajno veću prodaju u maloprodajnim lancima" (Makedonija, proizvođač).
„Supermarketi i hipermarketi su dominantni zbog karakteristika potrošača" (Republika Srbija, proizvođač).

Značaj maloprodajnih lanaca će porasti u budućnosti. Međutim, treba uzeti u obzir i HORECA kanal. Proizvođači će se odlučiti za najefikasniji kanal distribucije.

Maloprodajni trendovi na tržištima ZB su pozitivni za proizvode sa NiZ izjavom. Veći formati će biti značajniji $\mathrm{u}$ budućnosti maloprodaje prehrambenih proizvoda, što će dozvoliti maloprodavcima da ponude veći i širi asortiman. Na manje razvijenim tržištima ZB, supermarketi i hipermarketi će igrati značajniju ulogu na maloprodajnom tržištu. Zbog toga će rast proizvoda sa NiZ izjavom u ovim zemljama biti veći sa promenom maloprodajne strukture.

\section{Razlozi i prepreke za proizvodnju i prodaju proizvoda sa NiZ izjavom}

Odgovaranje na zahteve potrošača predstavlja glavni motiv i za proizvođače i za maloprodavce $u$ većini ispitivanih kategorija, iako njihovi spontani odgovori variraju u zavisnosti od kategorije, što se može videti na Slici 1. Potrošači se pominju u nekoliko različitih

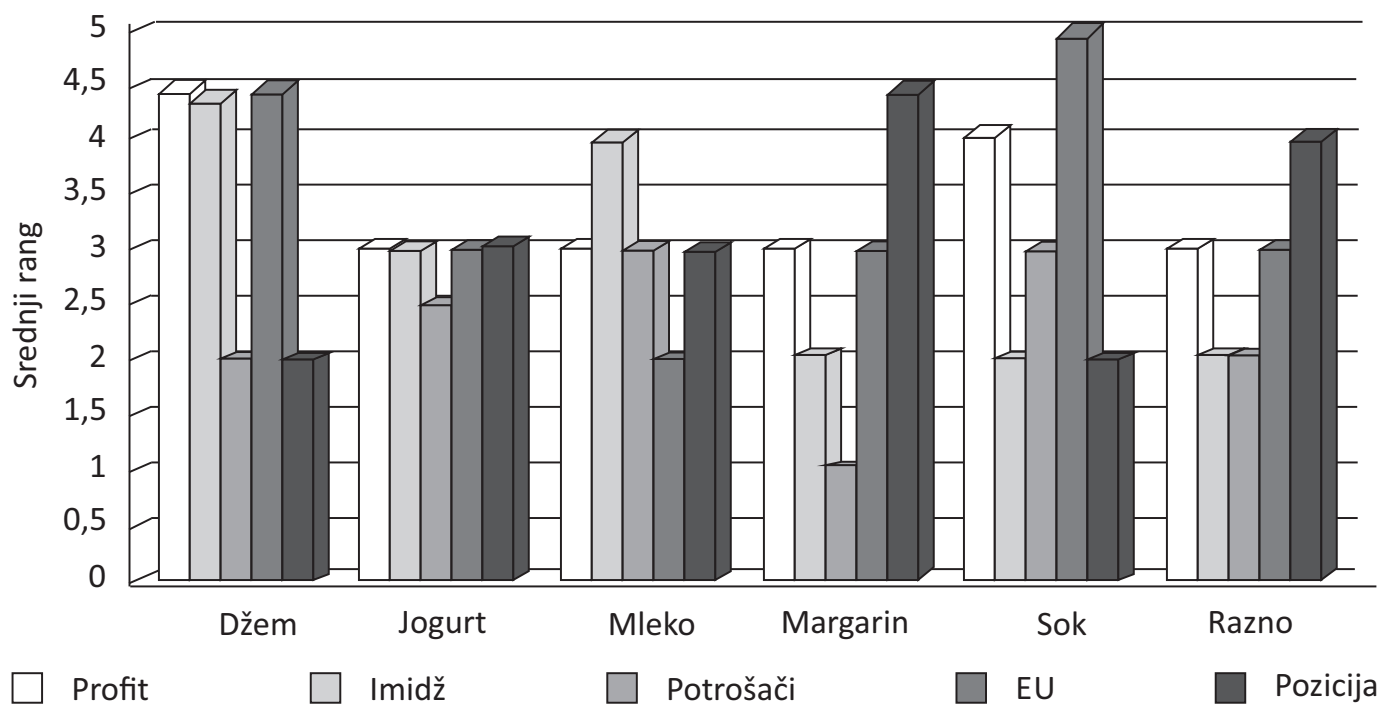

Slika 1 Razlozi proizvođača za proizvodnju proizvoda sa NiZ izjavom 
konteksta. Proizvođači džema za osobe koje boluju od dijabetesa, jogurta sa probioticima i niskokaloričnih margarina smatraju da ove proizvode proizvode prevashodno da bi odgovorili na tražnju njihovih potrošača. Kao drugi najvažniji razlog za proizvodnju proizvoda sa NiZ izjavom navode poboljšanje tržišnog položaja i imidža kompanije. Praćenje trendova iz EU i generisanje profita predstavljaju najmanje važne motive.

Kao što je prikazano na Slici 2, propisi i nedovoljno poznavanje potreba potrošača smatraju se najvećim problemima u razvoju tražnje za proizvodima sa NiZ izjavom. Ovi problemi su, takođe, istaknuti u spontanim odgovorima proizvođača. Međutim, s obzirom na to da prosečne ocene nisu visoke (već su do $3,5)$, to po mišljenju proizvođača nisu ozbiljne barijere. Nedostatak naučne podrške $u$ razvoju inovacija i finansijski problemi sledeći su na listi barijera. Najmanje važna prepreka je nedostatak stručnjaka i veština iz oblasti istraživanja i razvoja.

Odgovori maloprodavaca pokazuju da je glavna motivacija za uključivanje posmatranih proizvoda $u$ asortiman unapređivanje imidža preduzeća prodajom zdrave hrane, kao i zadovoljavanje potreba potrošača.
„Poboljšanje imidža preduzeća je prvi motiv. Mi prodajemo zdrave proizvode, sa sertifikatom, što ima uticaja na naše potrošače i njihovo poverenje $u$ naš maloprodajni lanac. Potrošači ove kategorije imaju viši nivo dohotka, i nama je bitno da oni dođu u naš supermarket. Da bismo zadovoljili potrebe potrošača i stekli njihovo poverenje, da obrazujemo potrošače po pitanju zdravstvenih pogodnosti proizvoda sa NiZ izjavom, da bi naše preduzeće postalo regionalni lider u prodaji ovih proizvoda" (Republika Srbija, maloprodavac).

Slično kao proizvođači, maloprodavci su „zadovoljenje potreba potrošača" rangirali kao najvažniji motiv, iza čega sledi unapređenje imidža kompanije. Motiv profita je na poslednjem mestu. To pokazuje da maloprodavci koriste ispitivane kategorije kao sredstva za pozicioniranje, i ne očekuju visok profit od njihove prodaje. Ipak, potrebna je opreznost kod tumačenja ovih rezultata, jer je stavljanje profita na poslednje mesto društveno poželjan odgovor. Pored toga, i ako su profit i praćenje EU trendova navedeni kao najmanje važni motivi, to ne znači da ovi kriterijumi nisu važni. Neke od kategorija generišu skromne obime prodaje u poređenju sa običnim proizvodima, zbog čega nisu profitabilni. Ipak, porast ovih kategorija uticaće na profitni motiv kompanija.

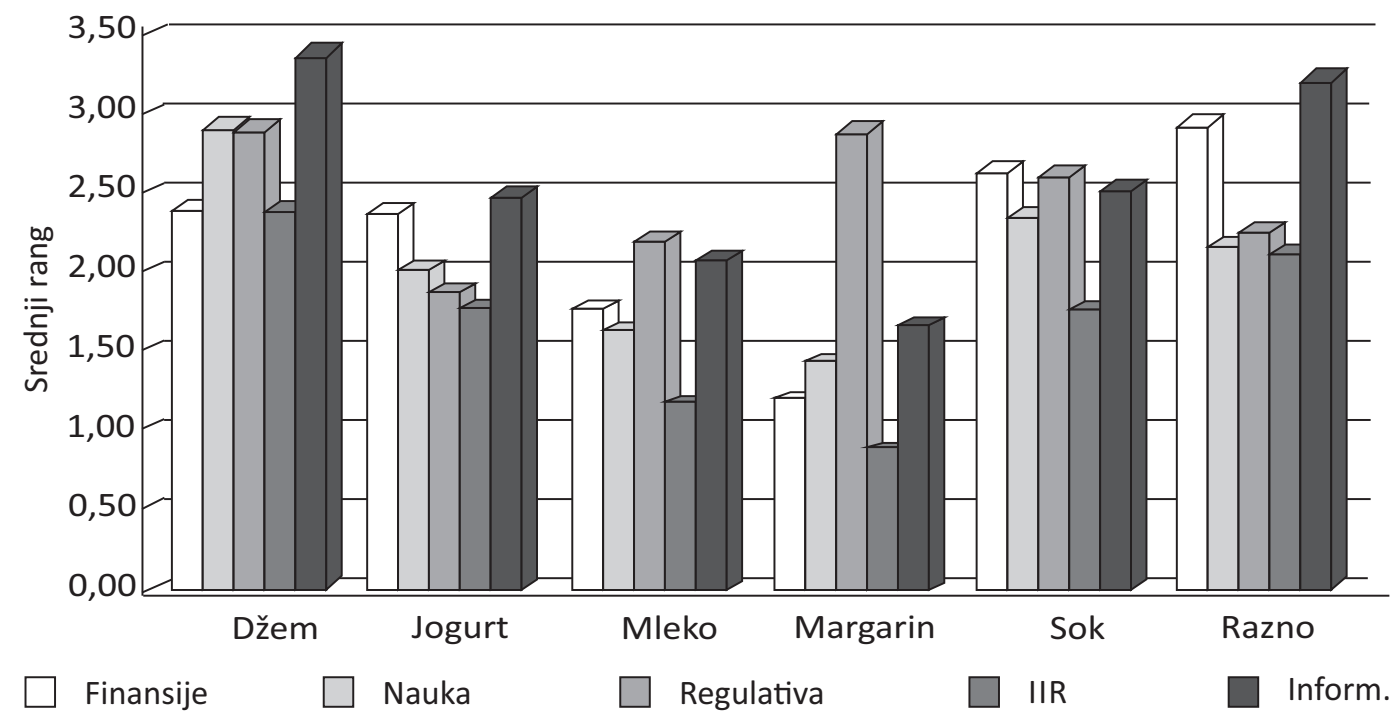

Slika 2 Prepreke u proizvodnji proizvoda sa NiZ izjavom 
Maloprodavci ističu da su glavne barijere za prodaju proizvoda sa NiZ izjavom u zemljama $Z B$ vezane za potrošače. Navike $u$ ishrani su glavni problem za maloprodavce, a prati ih svest potrošača i niska tražnja. Potrošači ne uključuju ove proizvode u svoju ishranu i nisu ih svesni što vodi niskoj tražnji. Maloprodavci ne smatraju odnose sa stranim kompanijama, logističke poteškoće i dostupnost proizvoda bitnim problemima na tržištima ZB.

\section{Percepcija tražnje}

Maloprodavci generalno očekuju porast tražnje za proizvodima sa NiZ izjavom u bliskoj budućnosti. Postoje značajne razlike $u$ percepciji tražnje maloprodavaca $\mathrm{u}$ različitim zemljma ZB. Naime, maloprodavci u Sloveniji i Hrvatskoj imaju relativno visoku tražnju, u Makedoniji je tražnja srednja, dok je tražnja maloprodavaca u Bosni i Hercegovini i Crnoj Gori prilično niska. U Republici Srbiji je tražnja nedovoljno visoka, različita $\mathrm{u}$ različitim regionima zemlje (veća u Beogradu i Vojvodini, nego u Centralnoj Srbiji). S druge strane, ukupno slaganje maloprodavaca sa izjavom: „Potrošačka tražnja za proizvodima sa nutritivnom i zdravstvenom izjavom je visoka danas" (1-uopšte se ne slažem, 5- slažem se u potpunosti) je malo niže od onog koje su izrazili proizvođači (2.82). Frekvencije odgovora pokazuju slične šablone, i najčešćom ocenom od 3 (12 od 28 maloprodavaca). Mada su samo dva maloprodavca (oba iz Slovenije) izrazila snažno slaganje sa izjavom (5), dok se tri maloprodavca uopšte ne slažu (Republika Srbija, Bosna i Crna Gora).

„Tražnja potrošača za proizvodima za nutritivnom i zdravstvenom izjavom raste. Do skoro su ovi proizvodi korišćeni samo od strane pojedinaca sa zdravstvenim problemima, ali sada imamo drugačiju situaciju. Veliki broj ljudi je razvio svest o zdravoj ishrani i kupuju ove proizvode iako nemaju zdravstvenih problema" (Makedonija, maloprodavac).

„Tražnja potrošača za proizvodima za nutritivnom i zdravstvenom izjavom je visoka" (Hrvatska, maloprodavac).

„Na vrlo je niskom nivou, delimično zbog visokih cena, ali više zbog obaveštenosti i navika u ishrani" (Bosna i Hercegovina, maloprodavac).
Zdravstvene koristi, kao faktor koji utiče na prehrambeni izbor potrošača je od rastućeg značaja, prema lokalnim proizvođačima i maloprodavcima u svim zemljama ZB. Iako je populacija vrlo cenovno osetljiva, postoji grupa potrošača koja je svesna funkcionalne hrane i njenih koristi, i spremni su da plate više da bi je dobili (Filipović \& Stojanović, 2012; Stojanović et al, 2013).

„Postaje sve važnije. Postoje potrošači koji kupuju specifičan proizvod koji je neophodan za njihovo zdravlje bez obzira na cenu. Takođe, neki od potrošača koji su sasvim svesni zdravstvenih koristi nekih prehrambenih proizvoda kupuju proizvode sa zdravstvenom i nutritivnom izjavom, iako nemaju nikakvih zdravstvenih problema" (Makedonija, maloprodavac).

„Zdravstvene pogodnosti su važan kriterijum prehrambenog izbora potrošača - jedan od najvažnijh kriterijuma" (Hrvatska, maloprodavac).

Uopšteno, ako se primeni na celokupnu populaciju zemalja ZB, cena je apsolutno najvažniji kriterijum prehrambenog izbora potrošača, uz dva izuzetka: 1) vezano za kategoriju proizvoda (ukus je bitniji od cene, kad je u pitanju margarin) i 2) razlike među zemljama: maloprodavci (za razliku od proizvođača) u Hrvatskoj smatraju da je cena najmanje važan kriterijum $u$ prehrambenom izboru potrošača, a u Makedoniji maloprodavci su veći rang dodelili dimenzijama bezbednosti i zdravlja nego ceni. Za proizvođače $\mathrm{u}$ Sloveniji, najmanje važan kriterijum je svežina.

Neobaveštenost o nutritivnosti, cene i ekonomske poteškoće su najčešće spontano navedena ograničenja $\mathrm{u}$ kupovini proizvoda sa NiZ izjavom u svim zemljama ZB. Ali proizvođači i maloprodavci smatraju da su neka od ograničenja od podjednake važnosti - neobaveštenost o nutritivnosti i navike bez eksplicitnih razlika među proizvodnim kategorijama. Suprotno ovome, jedino ograničenje koje je smatrano najmanje važnim je dostupnost, što znači da su takvi proizvodi generalno dostupni lokalnim potrošačima na zadovoljavajućem nivou.

„Glavno ograničenje u kupovini proizvoda sa NiZ izjavom je cena (viša cena)" (Hrvatska, maloprodavac).

„Neobaveštenost, visoke cene, ali najvažnije su navike u ishrani" (Bosna i Hercegovina, maloprodavac). 
„Finansijska situacija je najvažniji problem” (Crna Gora, maloprodavac).

Maloprodavci u zemljama ZB, uglavnom dele mišljenje sa proizvođačima: u Crnoj Gori smatraju da su nutritivna obaveštenost i cena najvažnija ograničenja potrošača pri izboru funkcionalne hrane; u Srbiji $\mathrm{su}$ to nutritivna obaveštenost i navike $u$ ishrani; $u$ Sloveniji cena i nutritivna neobaveštenost; $\mathrm{u}$ Hrvatskoj ekonomske poteškoće i cena; u Makedoniji nutritivna neobaveštenost; a u BiH navike u ishrani, ekonomske poteškoće i dostupnost.

Ono što je zanimljivo to je da strani izvoznici na tržišta ZB takođe smatraju nutritivnu neobaveštenost (osim u Sloveniji), zajedno sa cenom (odnosno ekonomskim uslovima) najvažnijim ograničenjima. Ponekad se pominje i slaba dostupnost ovih proizvoda u manje razvijenim zemljama Zapadnog Balkana. Lokalni proizvođači i maloprodavci smatraju da je dostupnost najmanje važno ograničenje, uz par izuzetaka.

„U lokalnoj prodavnici, šanse da se vidi ili kupi specifičan proizvod su vrlo male. Lokalne prodavnice uglavom su snabdevene običnim proizvodima i nema dovoljno izbora različitih proizvoda" (Makedonija, maloprodavac).

„Mala dostupnost proizvoda, navike u ishrani, ekonomska situacija, nedostatak svesti o nutritivnoj i zdravstvenoj vrednosti hrane" (Bosna i Hercegovina, maloprodavac).

\section{ZAKLJUČAK}

Osnovni doprinos rada je što omogućava bolje razumevanje značaja proizvoda sa NiZ izjavom na tržištima zemalja ZB. Potvrđena je hipoteza da navedeno tržište nije dovolino razvijeno na prostoru ZB. Posmatrani proizvodi postoje i počinju da imaju značaj na tržištu. Međutim, stepen razvoja se značajno razlikuje u zavisnosti od stepena razvijenosti zemlje. Druga hipoteza je, takođe, potvrđena i značaj ovih proizvoda ć rasti na tržištima ZB. Tražnja za proizvodima sa NiZ izjavom će se povećavati u budućnosti, po mišljenju svih privrednih činilaca zemalja Zapadnog Balkana. Međutim, do značajnijeg rasta će doći u srednjem i dugom roku. Pretpostavljeno povećanje biće izazvano rastom prosečnih prihoda na prvom mestu, s obzirom na to da se $\mathrm{u}$ trenutnoj ekonomskoj situaciji potrošači odlučuju za ono što mogu da priušte. Glavni faktor promene biće viši životni standard stanovništva, jer kada imaju veće prihode oni mogu da priušte proizvode visokog kvaliteta, uključujući i one sa NiZ izjavom.

Pored prihoda i ukupne ekonomske situacije, i znanje ima važnu ulogu u rastu tražnje za proizvodima sa NiZ. Prema rečima intervjuisanih predstavnika, sa programima obrazovanja potrošača mora da se počne što pre, naročito zbog loših navika $\mathrm{u}$ ishrani stanovništva. Dalje se kao bitan faktor ističe i prihvatanje promena načina života. Sve veća orijentacija stanovnika ZB ka stilu života stanovnika EU dovešće do ubrzanog preuzimanja takvog stila potrošnje, koji karakteriše veći udeo hrane sa NiZ izjavom u ishrani, nego što je to sada slučaj. Ipak, neophodno je istaći da je prema mišljenju eksperata ZB region za pet ili više godina iza trendova u EU. Opšti je konsenzus proizvođača da su spremni da stave proizvode sa NiZ izjavom na tržište, ali da tržište, to jest, potrošači, još uvek nisu spremni za ovu kategoriju proizvoda. S druge strane, izvoznici ukazuju na to da će ubrzanje potrošnje proizvoda sa NiZ izjavom biti veća nego u zemljama EU.

Takođe, važno je napomenuti da se zdravi proizvodi često smatraju kao ",kišobran” za različite kategorija proizvoda (na primer, prirodni proizvodi - bez konzervansa i veštačkih dodataka ili čak organski proizvodi). Iako ispitanici ne smatraju da su ovi proizvodi orijentisani samo na ljude sa zdravstvenim problemima, često se sugeriše da zdravstveno stanje stanovništva može biti značajan faktor oblikovanja preferencija potrošača u pogledu tražnje za proizvodima sa NiZ izjavom u budućnosti. Evidentno je da pitanja kao što su zdravlje, gojaznost dece i održivost dolaze sve više širom sveta $u$ fokus javnosti i izazivaju zabrinutost. Samim tim, vlade će se usredsrediti na održivost i zdravlje. Sledeći važan aspekt koji će uticati na trend rasta kategorije proizvoda sa NiZ izjavom je komunikacija.

Maloprodavci su istakli značaj saradnje među stakeholder-ima na razvoju tržišta proizvoda sa NiZ izjavom. U zemljama gde NiZ trgovinske marke nisu razvijene, maloprodavci i dalje misle da bi proizvođači 
trebalo da povedu ovaj proces. Oni, takođe, smatraju da domaće kompanije nisu dovoljno motivisane da bi ponudile ove proizvode na tržištu. Mišljenje maloprodavaca je, ipak, malo drugačije po pitanju glavnih faktora promene tražnje za proizvodima sa NiZ izjavom. Najvažniji faktori promene su povezani sa nutricionom obaveštenošću, obrazovanjem i aktivnošću javne politike $u$ promociji zdravijeg života u zemljama ZB. Mnogo manji značaj je dodeljen modi i kupovnoj moći potrošača, što bi moglo biti potvrđeno maloprodajnim formatom ispitanih kompanija. Naime, oni većinom koriste hipermarkete i supermarkete u okviru urbanih područja razvijenih regiona zemalja. Njihova specifična ciljna populacija je i bolje obrazovana i pripada populaciji sa višim dohotkom.

U budućnosti treba očekivati značajnije uključivanje maloprodavaca $\mathrm{u}$ lansiranje novih proizvoda sa NiZ izjavom. Naime, nagli razvoj trgovinske marke i težnja da se bude konkurentan ne samo po cenama, već i po kvalitetu i širini asortimana već sada navodi maloprodavce da razmišljaju o lansiranju sopstvenih proizvoda sa NiZ izjavom. Ovaj trend će biti izraženiji u budućnosti na prostorima ZB jer se očekuje značajan rast trgovinske marke u posmatranim kategorijama.

Na kraju treba pomenuti da će na buduću potrošnju hrane sa NiZ izjavom uticati i novi zakon u vezi sa proizvodima sa zdravstvenim izjavama u EU i odsustvo državne podrške za razvoj sektora funkcionalne hrane na ZB.

Usled dejstva novog zakona postoji velika verovatnoća da će tražnja za ovim proizvodima biti ograničena ili čak smanjena. Takođe, poverenje potrošača $u$ izjave je od krucijalne važnosti. Razvoj poverenja može biti snažno povezan sa propisima o ishrani i zdravstvenim izjavama. Dok su nutritivne izjave regulisane u svim zemljama $\mathrm{ZB}$, zdravstvene izjave su pravno rešene samo u Sloveniji i Hrvatskoj. Veoma je važno da izjave ne dovode potrošače $u$ zabludu. Iz ugla proizvođača nameće se jedna od najjačih prepreka za budući razvoj ovog tržišta, a to je činjenica da proizvođači misle da ne postoji nacionalna politika za ishranu. Neophodno je poboljšati regulativu i to jasno objasniti proizvođačima.

Tržište proizvoda sa NiZ izjavom predstavlja mlado tržište, naročito na prostoru $\mathrm{ZB}$, prisutno tek nešto više od deceniju. Ipak, veliki rast istog, zajedno sa konstantnim povećanjem novih potrošača ove kategorije proizvoda na globalnom, evropskom i balkanskom nivou, zahteva njegovo dublje razumevanje i sprovođenje daljih istraživanja u cilju potpunijeg razumevanja potrošača proizvoda sa NiZ izjavom, kako bi se ka njima usmerile efikasne marketinške komunikacije, ostvarilo profitabilno poslovanje i unapredilo zdravstveno stanje lokalnog stanovništva.

S obzirom na vrlo malo relevantnih istraživanja i podataka o ovoj temi, rezultati ovog kvalitativnog istraživanja su doprineli boljem razumevanju marketing strategije proizvođača i maloprodavaca kada su u pitanju proizvodi sa NiZ izjavom.

Treba napomenuti sa sprovedeno istraživanje ima svoja ograničenja. S obzirom na to da je u pitanju kvalitativno istraživanje, kvantitativna dimezija nedostaje. Takođe, u uzorku dominiraju srednja i velika proizvodna i trgovinska preduzeća. Istraživanje je ograničeno na 5 kategorija proizvoda.

Budući pravci istraživanja mogli bi da otklone navedene nedostatke. Sprovođenjem kvantitativnih istraživanja kako na uzorcima proizvođača i maloprodavaca, tako i na uzorku potrošača omogućila bi da se dobije precizna slika o veličini i značaju navedenog tržišta. Neophodno je uključiti i male proizvođače i maloprodavce $u$ istraživanje jer je njihova perspektiva takođe veoma relevantna. Pored toga, bilo bi interesantno da se istraže i druge kategorije proizvoda sa NiZ izjavom.

\section{ZAHVALNICA}

Istraživanje koje je dovelo do ovih rezultata sprovedeno je u okviru projekta Sedmog okvirnog programa Evropske unije (FP7 2007-2013), pod ugovorom granta 212579.

\section{REFERENCE}

Caswell, J. A., \& Padberg, I. D. (1992). Toward a More Comprehensive Theory of food Labels. American Journal of Agricultural Economics, 74(2), 460-468. 
Caswell, J. A., \& Mojduszka, E. M. (1996). Using Informational Labeling to Influence the Market for Quality in Food Products. American Journal of Agricultural Economics, 78(5), 1248-1253.

Caswell, J. A., \& Johnson G. V. (1991). Firm Strategic Response to Food Safety and Nutrition Regulation. In J. A. Caswell (Ed.), Economics of Food Safety (pp. 273-297). New York: Elsevier Science Publishing Co.

Christidis, N., Tsoulfa, G., Varagunam, M., \& Babatzimopoulou, M. (2011). A cross sectional study of consumer awareness of functional foods in Thessaloniki, Greece. Nutrition \& Food Science, 41(3), 165-174.

Dimić, E. B., Vukša, V. L., \& Dimić, V. (2002). Margarin i masni namazi kao funkcionalna hrana. Uljarstvo, 33(3-4), 3-8.

Dimitrijević-Branković, S. I., Baras, J. K., i Bojović, J. (2002). Značaj i mogućnosti proizvodnje funkcionalne hrane. Hemijska industrija, 56(3), 113-122.

Diplock, A. T., Agget, P. J., Ashwell, M., Bornet, F., Fern, E. B., \& Roberfroid, M. B. (1999) Scientific concepts of functional foods in Europe: consensus document. British Journal of Nutrition, 81(1), S1-S27.

Euromonitor. (2012). Fortified/functional packaged food: market sizes. London: Euromonitor International

Filipović, J., \& Stojanović, Ž. (2012). Serbian consumer acceptance of functional foods: sociodemographic and attitudinal determinants. In V. Babić (Ed.), Contemporary Issues in Economics, Business and Management (pp. 179-188), Kragujevac: Faculty of Economics University of Kragujevac.

Grujić, R. (2005). Food Labeling. In Grujić, R., \& V. Sanchis (Eds.) Proceedings of Final TEMPUS Seminar (pp. 105-120), Banja Luka.

Heasman, M., \& Mellentin, J. (2001). The Functional Foods Revolution: Healthy People, Healthy Profits? London: Earthscan Publications.

Hojoon, C., Kyunga, Y., Tae, H. B., Reid, L. N., \& Macias, W. (2013). Presence and effects of health and nutrition-related (HNR) claims with benefit-seeking and risk-avoidance appeals in female-orientated magazine food advertisements. International Journal of Advertising, 32(4), 587-616.

Kapsak, W. R., Rahavi, E. B., Childs, N. M., \& White, C. (2011). Functional Foods: Consumer Attitudes, Perceptions, and Behaviors in a Growing Market. Journal of the American Dietetic Association, 111(6), 804-810.
Koch, V., \& Pokorn, D. (1999). Comparison of nutritional habits among various adult age groups in Slovenia. Nutritional Research, 19(8), 1153-1164.

Ljaljević A., Durišić B., Mališić N., \& Ivanović Lj. (2006). The volume of nutrition elements from milk and eggs in the acerage daily nutrition of the Montenegrin population compared to the recommended daily nutrition components volume. Podgorica: Institute for public health of Montenegro.

Markovina, J., Čačić, J., Kljusurić, J. G., \& Kovačić, D. (2011). Young consumers' perception of functional foods in Croatia. British Food Journal, 113(1), 7-16.

Miletić, I., Šobajić, S., \& Đorđević, B. (2008). Funkcionalna hrana - uloga u unapređenju zdravlja. Journal of Medical Biochemistry, 27(3), 367-370.

Patel, A. (2012). The regulation of health and nutrition claims for the promotion of food. International Journal of Management Cases, 14(1), 340-346.

Raspor, P., \& Jevsnik, M. (2008). Good Nutritional Practice from Producer to Consumer. Food Science and Nutrition, 48(3), 276-292.

Ristevska-Jovanovska, S. (2007). Промени во заштитата на потрошувачите во ЕУ согласно со програмата 2007-2013 и состојбите во Република Македонија. Annual of the Faculty of Economics, 42, 39-48

Ristić, G. (2003). Funkcionalna hrana - hrana za XXI vek. Mlekarstvo, 2(14), 428-433.

Rogelj, I. (2000). Funkcionalna hrana - hrana budućnosti, Prehrambena industrija. Mleko i mlečni proizvodi, 11(1-2), 4042

Stanković, I. M. i Đorđević, B. I. (2002). Funkcionalna i nekonvencionalna hrana - zakonska regulativa. Hrana $i$ ishrana, 43(1-2), 60-62.

Stojanović, Ž., Dragutinović-Mitrović, R., \& Zaouche-Laniau, M. (in press). Products with nutrition and health claims in the Western Balkans: labelling behaviour, regulation and policy implications. European Journal of Law and Economics.

Stojanović, Ž., Filipović, J., \& Mugoša, B. (2013). Consumer acceptance of functional foods in Montenegro. Montenegrin Journal of Economics, 9(3), 65-74.

Šobajić, S. (2002). Funkcionalna hrana u prevenciji bolesti i terapiji. Arhiv za farmaciju, 52(3), 369-375. 
Žaklina Stojanović je redovni profesor Ekonomskog fakulteta Univerziteta u Beogradu. Predaje Agrarnu ekonomiju na osnovnim, kao i predmete koji su povezani sa agrarom na diplomskim i doktorskim akademskim studijama. Redaktor je šest monografija i autor tri knjige, kao i više od 100 članaka iz oblasti ekonomika agrara, ruralni razvoj i agrarne finansije.

Jelena Filipović je docent na predmetima Tržišno komuniciranje i Marketing usluga, na Ekonomskom fakultetu Univerziteta u Beogradu. Njen istraživački fokus uključuje: Internet komunikacije, decu kao potrošače i marketing prehrambenih proizvoda. Objavljivala je u: International Marketing Review, Communications and Strategies, Ekonomika poljoprivrede.

Dragan Stojković je docent na Ekonomskom fakultetu Univerziteta u Beogradu, na nastavnim predmetima Kanali marketinga, Trgovinski marketing i menadžment prodaje, Elektronska trgovina. Njegov naučno-istraživački fokus uključuje: maloprodajni marketing i menadžment, elektronsku trgovinu. Objavio je veći broj radova. 


\title{
MARKETS OF FOOD WITH NUTRITIVE AND HEALTH CLAIM: PRODUCERS' AND RETAILERS'PERSPECTIVES
}

\author{
Zaklina Stojanovic, Jelena Filipovic, Dragan Stojkovic \\ Faculty of Economics, University of Belgrade, Belgrade, Serbia
}

\begin{abstract}
Although food with nutritive and health claims in the Western Balkan countries hasbeen present in this region for more than a decade, it has remained rather understudied. Therefore, the aim of this study was to determine the importance of products with nutritive and health claims in the Western Balkans, using qualitative research techniques. In the study, the prices and margins of the subject product group, distribution channels, demand perception and incentives as well as barriers for the future development of the functional food market were analyzed. The study included five categories of products with nutritive and health claims, whilethe technique of the in-depth interviews was adopted. The total of 29 producers and 26 retailers form all the six countries of the region participated in the research. Even thoughthe studied categories recorded a sales growth in the previous period, a significant increase is expected in the mediumand long term, along with the growth of the living standard - given that products with nutritive and health claims are more expensive than regular ones. The results imply that it is necessary that the level of education regarding the role of food in health preservation should be raised; and that a change inbad eating habits should be influenced. The development of functional food markets also requires a government support and an appropriate legislation.
\end{abstract}

Keywords: functional food, nutritive claim, health claim, the Western Balkans markets

JEL Classification: D12, 115, M38 